\title{
Expansive Soil Characterisation: an Appraisal
}

\author{
Sridharan Asuri ${ }^{1} \cdot$ Prakash Keshavamurthy $^{2}$
}

Received: 31 March 2016/Accepted: 8 April 2016/Published online: 27 April 2016

(c) Indian National Academy of Engineering 2016

\begin{abstract}
Expansive soils, which are considered as problematic soils, have worldwide distribution and hence, their proper identification and characterisation becomes an absolute necessity in the perspective of the present day geotechnical engineering practice. This paper intends to discuss relative merits of various methods available to a field geotechnical engineer to achieve this important goal.
\end{abstract}

Keywords Characterisation - Clay mineralogy · Expansive soils - Free swell tests - Testing methods

\section{Introduction}

Any soil whose volume changes are moisture sensitive is normally considered as an expansive soil. Expansive soils are regarded as problematic soils as they affect the stability of structures founded on them. Hence, it becomes very essential for a practicing geotechnical engineer to appropriately identify and characterise such soils. This in turn will help in material, time, financial and human resource managements, which are the essential components of any project management.

The expansive soils are characterised by the presence of expanding lattice type of clay minerals belonging to

Prakash Keshavamurthy

kprakash60@yahoo.com

Sridharan Asuri

sridharanasuri@yahoo.com

1 FNAE, Indian National Academy of Engineering, New Delhi, India

2 Department of Civil Engineering, Sri Jayachamarajendra College of Engineering, Mysuru 570 006, India smectite group, montmorillonite being an important member of that group. These clay minerals are characterised by

- Very weak van der Waals' forces in between the adjacent unit cells of the mineral.

- Appreciable isomorphous substitution during the clay mineral formation, leading to very high negative surface charges.

- Very high cation exchange capacity (i.e., $80-150$ meq/ $100 \mathrm{~g}$ )

- Large specific surface (i.e., $400-900 \mathrm{~m}^{2} / \mathrm{g}$ ).

It has been well established that these minerals respond quite differently to any external physico-chemical environment when compared with the response of non-expanding lattice type of clay minerals like kaolinite, which may also be present in any natural soil.

\section{Characterisation of Expansive Soils}

Various criteria adopted to recognise the presence of expanding lattice type clay minerals in a natural soil can be broadly classified into two categories namely, mineralogical identification and inferential testing methods.

\section{Mineralogical Identification Methods}

The techniques belonging to this category of methods are:

- X-ray diffraction analysis.

- Differential thermal analysis.

- Dye adsorption.

- Chemical analysis.

- Scanning electron microscopy. 
Chen (1988) opined that these techniques should be used in combination for better and reliable results. However, these techniques have restricted usage and are confined to research laboratories only in view of their requirement of sophisticated and specialised instrumentation, which are costly and also expert interpretation of the resulting data.

\section{Inferential Testing Methods}

These methods try to link some of the index properties of fine-grained soils with the soil clay mineralogical composition and hence, to estimate their swell potential. They can be classified as indirect methods and direct methods.

\section{Indirect Methods}

These methods make use of soil index properties such as liquid limit, shrinkage limit, percent clay size composition of soils and also some of the indices such as plasticity index, shrinkage index and the like to estimate the swell potential of soils.

1. Liquid limit related properties:

- Liquid limit: This upper bound plasticity limit is determined in the laboratory by the conventional Casagrande method or by the fall cone method. Liquid limit of a soil is regarded as the water holding capacity of the soil, which in turn has been taken as a measure of soil swell potential. Many classification schemes are available in the geotechnical engineering literature to recognise the degree of soil swell potential based on the liquid limit of fine-grained soils (Table 1).

- Plasticity Index: It is the difference between the liquid limit and plastic limit of fine-grained soils. Higher the plasticity index, more plastic the soil is and higher will be the soil swell potential. Different schemes available to recognise the soil expansivity based on the plasticity index of the soils are given in Table 2.

The indirect methods of characterising the soil swell potential suffer from the following limitations:

Table 1 Expansive soil classification based on liquid limit

\begin{tabular}{llll}
\hline Swell potential & \multicolumn{3}{l}{ Liquid limit $(\%)$} \\
\cline { 2 - 4 } & $\begin{array}{l}\text { Chen } \\
(1965)\end{array}$ & $\begin{array}{l}\text { Snethan et al. } \\
(1977)\end{array}$ & $\begin{array}{l}\text { IS: 1498 } \\
(1970)\end{array}$ \\
\hline Low & $<30$ & $<50$ & $20-35$ \\
Medium/marginal & $30-40$ & $50-60$ & $35-50$ \\
High & $40-60$ & $>60$ & $50-70$ \\
Very high & $>60$ & - & $70-90$ \\
\hline
\end{tabular}

Table 2 Expansive soil classification based on plasticity index

\begin{tabular}{|c|c|c|c|}
\hline \multirow{2}{*}{$\begin{array}{l}\text { Swell } \\
\text { potential }\end{array}$} & \multicolumn{3}{|c|}{ Plasticity index (\%) } \\
\hline & $\begin{array}{l}\text { Holtz and Gibbs } \\
\text { (1956) }\end{array}$ & $\begin{array}{l}\text { Chen } \\
(1988)\end{array}$ & $\begin{array}{l}\text { IS: } 1498 \\
(1970)\end{array}$ \\
\hline Low & $<18$ & $0-15$ & $<12$ \\
\hline Medium & $15-28$ & $10-35$ & $12-23$ \\
\hline High & $25-41$ & $20-55$ & $23-32$ \\
\hline Very high & $>35$ & $>35$ & $>32$ \\
\hline
\end{tabular}

Table 3 Expansive soil classification based on shrinkage limit (Holtz and Gibbs 1956)

\begin{tabular}{ll}
\hline Swell potential & Shrinkage limit $(\%)$ \\
\hline Low & $>15$ \\
Medium & $10-16$ \\
High & $7-12$ \\
Very high & $<11$ \\
\hline
\end{tabular}

Table 4 Expansive soil classification based on shrinkage limit (Altmeyer 1956)

\begin{tabular}{ll}
\hline Volume change & Shrinkage limit $(\%)$ \\
\hline Non-critical & $>12$ \\
Marginal & $10-12$ \\
Critical & $<10$ \\
\hline
\end{tabular}

- The liquid limit tests are empirical and strength based (Sridharan and Prakash 1998a).

- There is no unique mechanism controlling the liquid limits of soils containing expanding lattice type clay minerals and the soils containing nonexpanding lattice type clay minerals (Sridharan et al. 1986, 1988).

- The mechanisms controlling the liquid limit of fine-grained soils and the mechanisms governing the test procedures (i.e., Casagrande method and fall cone method) may not match (Sridharan and Prakash 2000a).

- Dependency of plasticity index on liquid limit.

2. Shrinkage limit related properties:

- Shrinkage limit: It represents the lower bound water content for any volume reduction of a soil mass and hence, regarded as a measure of volume stability of the in situ soil. Tables 3 and 4 present the schemes available to recognise the swell potential of finegrained soils based on shrinkage limit.

- Shrinkage Index: It is defined by the Bureau of Indian Standards (IS: 2809 1972) as the difference between plastic limit and shrinkage limit. The 
Table 5 Expansive soil classification based on shrinkage index (IS 1498)

\begin{tabular}{ll}
\hline Degree of expansivity/swell potential & Shrinkage index $(\%)$ \\
\hline Low & $<15$ \\
Medium & $15-30$ \\
High & $30-60$ \\
Very high & $>60$ \\
\hline
\end{tabular}

Table 6 Expansive soil classification based on particle size composition

\begin{tabular}{lll}
\hline $\begin{array}{l}\text { Degree of } \\
\text { expansivity/swell } \\
\text { potential }\end{array}$ & $\begin{array}{l}\text { Percent clay size } \\
\text { fraction (Chen 1965) }\end{array}$ & $\begin{array}{l}\text { Colloid content (Holtz } \\
\text { and Gibbs 1956) }\end{array}$ \\
\hline Low & $<30$ & $<15$ \\
Medium & $30-60$ & $13-23$ \\
High & $60-95$ & $20-31$ \\
Very high & $>95$ & $>28$ \\
\hline
\end{tabular}

classification of swell potential of fine-grained soils based on their shrinkage index is given in Table 5 .

It has been noted by many researchers that the shrinkage limit and the shrinkage index are not good predictors of the swell potential of fine-grained soils. This is because that the shrinkage limit is not a plasticity characteristic of finegrained soils and that the mechanism controlling the shrinkage limit is quite different from the mechanism controlling the soil swelling. While the soil swelling is controlled by the presence of expanding lattice type of clay minerals, the shrinkage limit is a result of packing phenomenon and is primarily controlled by the relative particle size distribution of fine-grained soils (Sridharan and Prakash 1998b).

3. Particle size composition related properties:

- Many researchers have proposed criteria based on percentage clay size fraction (i.e., $<0.002 \mathrm{~mm}$ size) or colloid content (i.e., content of particles of size less than $0.001 \mathrm{~mm}$ ) to predict the swell potential of fine-grained soils, as per the scheme given in Table 6.

- Activity: Activity of a soil is normally calculated as the ratio of plasticity index of the soil to its percentage clay size fraction. The soils can be classified based on their activity according to the guidelines given in Table 7 .

The classification criteria based on particle size related properties have very strong limitations:

- The swelling of the soil is due to the amount of expanding lattice type clay minerals present in the soil
Table 7 Expansive soil classification based on the activity

\begin{tabular}{lll}
\hline Activity $\left(A_{\mathrm{c}}\right)$ & Nature of the soil & $\begin{array}{l}\text { Probable degree } \\
\text { of swell potential }\end{array}$ \\
\hline$<0.75$ & Inactive & Low \\
$0.75-1.25$ & Normal & Medium \\
$>1.25$ & Active & High \\
\hline
\end{tabular}

Table 8 Expansive soil classification based on oedometer swell tests

\begin{tabular}{lll}
\hline Swell potential & $\begin{array}{l}\text { \% Expansion in oedometer } \\
\text { (Holtz and Gibbs 1956) }\end{array}$ & $\begin{array}{l}\text { \% Expansion } \\
\text { in oedometer } \\
\text { (Seed et al. 1962) }\end{array}$ \\
\hline Low & $<10$ & $0-1.5$ \\
Medium & $10-20$ & $1.5-5$ \\
High & $20-30$ & $5-25$ \\
Very high & $>30$ & $>25$ \\
\hline
\end{tabular}

rather than the percentage of clay size fraction present in the soil.

- The percent clay size fraction or colloid content of a soil is determined by the sedimentation analysis (Ex: hydrometer analysis), which is based on many unrealistic assumptions.

\section{Direct Methods}

The methods coming under this category measure the swell potential of a soil directly.

1. Oedometer Tests: According to Winterkorn and Fang (1986), the most useful and reliable assessment of swell potential of a soil could be obtained from the conventional oedometer swell tests.

According to USBR (Holtz and Gibbs 1956), the criterion for the classification of degree of soil expansivity is the total volume change of a soil from air dry to a saturated condition under a surcharge of $7 \mathrm{kPa}$ in an oedometer (Table 8).

According to Seed et al. (1962), the criterion for the classification of degree of soil expansivity is the percent expansion exhibited by the soil compacted at maximum dry density and OMC under a surcharge of $7 \mathrm{kPa}$ (Table 8).

The major limitations of oedometer tests are that they are tedious to perform and are time consuming.

2. Free swell tests:

- Free Swell Value (FSV) Test: This test was first proposed by Holtz and Gibbs (1956). This test consists of pouring slowly $10 \mathrm{~cm}^{3}$ of oven dried soil passing $425 \mu \mathrm{m}$ sieve into a $100 \mathrm{~cm}^{3}$ measuring jar filled with distilled water and noting the 


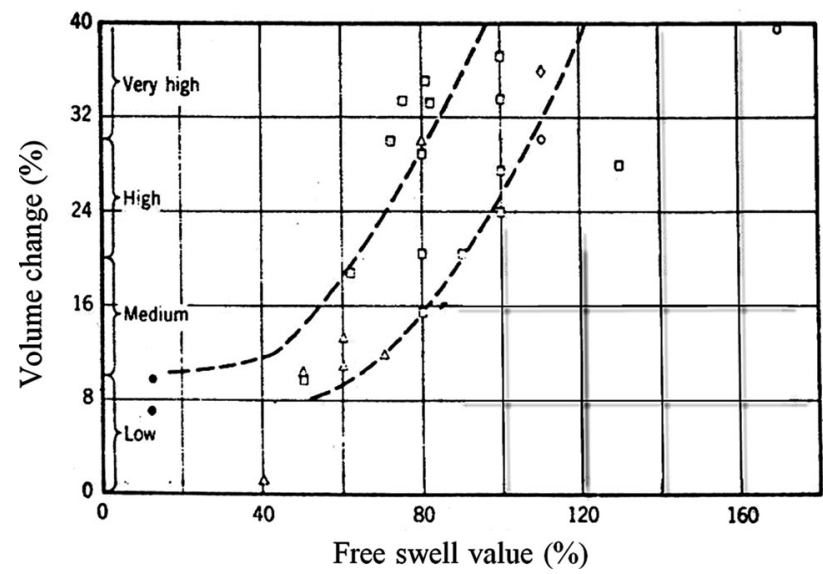

Fig. 1 Relationship between free swell value and volume change (air dry to saturated condition under a load of $7 \mathrm{kPa}$ ) (Holtz and Gibbs 1956)

equilibrium volume of the sediment formed. The free swell value is then calculated as the increase in the volume of the soil expressed as a percentage of the initial volume.

Holtz and Gibbs (1956) had not advised any specific values of free swell to classify the soils. However, they suggested a pictorial relationship between FSV and the volume change of undisturbed soil specimens placed in the laboratory consolidometer from air dry to saturated condition under a load of about $7 \mathrm{kPa}$ (i.e. 1 psi) (Fig. 1). The other limitation of this method is that the mass of the soil contained in $10 \mathrm{~cm}^{3}$ dry volume is a variable. Measurement of $10 \mathrm{~cm}^{3}$ volume of dry soil is purely based on personnel judgement, and it does not account for the variation in density of the soil, which is dependent on the height of pouring of the soil into the jar.

- Differential Free Swell Test: In this method, which is a standard method of practice specified by the Bureau of Indian Standards (IS: 2720 1977), the initial dry mass of the soil to be taken for the free swell test is $10 \mathrm{~g}$, thus overcoming the limitation of the free swell volume test. In this method, the free swell index is defined by the Eq. (1).

$F S I(\%)=\left[\frac{V_{d}-V_{k}}{V_{k}}\right] 100$

where, $\mathrm{V}_{\mathrm{d}}$ and $\mathrm{V}_{\mathrm{k}}$ are the equilibrium sediment volumes of $10 \mathrm{~g}$ oven dried soil samples passing $425 \mu \mathrm{m}$ sieve placed in $100 \mathrm{ml}$ graduated measuring jars containing distilled water and kerosene respectively, after an equilibration period of a minimum of $24 \mathrm{~h}$. The swell potential of the soil based on FSI is classified as per the guidelines given in Table 9.
Table 9 Expansive soil classification based on FSI (IS 1498 1970)

\begin{tabular}{ll}
\hline Swell potential & FSI $(\%)$ \\
\hline Low & $<50$ \\
Medium & $50-100$ \\
High & $100-200$ \\
Very high & $>200$ \\
\hline
\end{tabular}

Table 10 Expansive soil classification based on FSR (Sridharan and Prakash 2000b)

\begin{tabular}{|c|c|c|c|}
\hline $\begin{array}{l}\text { Free swell } \\
\text { ratio }\end{array}$ & Clay type & $\begin{array}{l}\text { Swell } \\
\text { potential }\end{array}$ & $\begin{array}{l}\text { Dominant clay } \\
\text { mineral type }\end{array}$ \\
\hline$\leq 1.0$ & Non-swelling & Negligible & Kaolinitic \\
\hline $1.0-1.5$ & $\begin{array}{l}\text { Mixture of } \\
\text { swelling and } \\
\text { non-swelling }\end{array}$ & Low & $\begin{array}{l}\text { Mixture of kaolinitic } \\
\text { and } \\
\text { montmorillonitic }\end{array}$ \\
\hline $1.5-2.0$ & Swelling & Moderate & Montmorillonitic \\
\hline $2.0-4.0$ & Swelling & High & Montmorillonitic \\
\hline$>4.0$ & Swelling & Very high & Montmorillonitic \\
\hline
\end{tabular}

The major limitation of the differential free swell method is that it gives negative free swell indices for kaolinite rich soils (Sridharan et al. 1985).

- Free swell ratio (FSR) method: Free swell ratio is defined as the ratio of the equilibrium sediment volume of $10 \mathrm{~g}$ oven dried soil sample passing $425 \mu \mathrm{m}$ sieve placed in $100 \mathrm{ml}$ graduated measuring jar containing distilled water to that in kerosene, after an equilibration period of a minimum of $24 \mathrm{~h}$. The guidelines to classify degree of expansivity of a soil based on its FSR are indicated in Table 10. Table 10 also gives the probable dominant clay mineral composition of the soil.

The merits of the free swell ratio method of characterising the expansive soils are listed below:

- The test procedure is very simple and user friendly.

- It does not require any sophisticated instrumentation and interpretation.

- The type of principal clay mineral(s) composing the soil can be predicted quite accurately.

- The test results have been validated with oedometer swell tests (Sridharan and Prakash 2000b).

- The predicted dominant clay mineral type composing the soil from the FSR method and the actual dominant clay mineral(s) composing the soil have been shown to have an excellent one-to-one match (Prakash and Sridharan 2004). 


\section{Conclusions}

Various methods of characterising expansive soils can be broadly grouped into two categories namely, mineralogical identification methods and inferential testing methods. This paper has discussed these two groups of methods and their sub groups critically and brought out the merits and limitations of various methods discussed. Free swell ratio method has been shown to be a simple and user friendly method that can be adopted in the field for characterising the expansive soils and for the identification of their mineralogical composition (Table 10).

\section{References}

Altmeyer WT (1956) Discussion. Transit ASCE 121:666-669

Chen FH (1965) The use of piers to prevent the uplifting of lightly loaded structure founded on expansive soil. In: Concluding proceedings engineering effects of moisture change in soils, international research and engineering conference on expansive clay soils. A\&M, Texas, pp 152-171

Chen FH (1988) Foundations on expansive soils. Elsevier, Amsterdam

Holtz WG, Gibbs HJ (1956) Engineering properties of expansive clays. Trans ASCE 121:641-663

IS: 1498 (1970) (reaffirmed 1987), Indian standard classification and identification of soils for general engineering purposes. BIS, New Delhi
IS: 2720 (1977) Part 40, Indian standard methods of test for soils: determination of free swell index of soils. BIS, New Delhi

IS: 2809 (1972) Indian Standard glossary of terms and symbols relating to soil engineering. BIS, New Delhi

Prakash K, Sridharan A (2004) Free swell ratio and clay mineralogy of fine-grained soils. Geotech Test J ASTM 27(2):220-225

Seed HB, Woodward RJ, Lundgren R (1962) Prediction of swelling potential for compacted clays. J Soil Mech Found Division ASCE 88(SM3):53-87

Snethan DR, Johnson LD, Patrick DM (1977) An evaluation of expedient of methodology for identification of potentially expansive soils. In: Soils and Pavements Lab, US Army Eng. Water Way Exp. Station, Vicksburg, MS, Report No. FHWARE-77-94, NTIS PB-289-164

Sridharan A, Prakash K (1998a) Characteristic water contents of a fine-grained soil-water system. Geotechnique 48(3):337-346

Sridharan A, Prakash K (1998b) Mechanism controlling the shrinkage limit of soils. Geotech Test J ASTM 21(3):240-250

Sridharan A, Prakash K (2000a) Percussion and cone methods of determining the liquid limit of soils: controlling mechanisms. Geotech Test J ASTM 23(2):236-244

Sridharan A, Prakash K (2000b) Classification procedures for expansive soils. Geotech Eng 143:235-240

Sridharan A, Rao SM, Murthy NS (1985) Free swell index of soils: a need for redefinition. Indian Geotech J 15(2):94-99

Sridharan A, Rao SM, Murthy NS (1986) Liquid limit of montmorillonite soils. Geotech Test J ASTM 9(3):156-159

Sridharan A, Rao SM, Murthy NS (1988) Liquid limit of kaolinitic soils. Geotechnique 38(2):191-198

Winterkorn HF, Fang HY (1986) Soil technology and engineering practices of soils. Foundation engineering hand book. Galgotia Book Source, New Delhi 